\title{
DNA Extraction and Application of SSR Markers in Genetic Identification of Grapevine Cultivars
}

\author{
Zorica Ranković-Vasić, Dragan Nikolić
}

\begin{abstract}
Microsatellite markers (SSR markers) are widely used in grapevine genetic research for identification of cultivars, parentage analysis, and genetic characterization of germplasm. Aim of this work was extraction of total DNA, primer selection and design, PCR protocols and analysis of DNA sequences with special emphasize on variability between collected samples of different grapevine cultivars. The material used in this study were samples of grapevine leaves of different autochthonous and introduced cultivars from grapevine collection on Experimental field "Radmilovac" at the Faculty of Agriculture, University in Belgrade and from the National fruit collection "Brogdale" from UK. Standard set of nine primers for grapevine was used. Analyses were performed in Molecular Genetics Laboratory, School of Agriculture, Policy and Development, University of Reading, Reading, UK. Extraction and purification of total DNA from fresh and frozen plant material (grapevine leaves) was performed using a DNeasy ${ }^{\circledR}$ Plant Mini (Qiagen Inc.) kit. The concentration of extracted DNA was measured by NanoDrop spectrophotometer and stored on $-20^{\circ} \mathrm{C}$ until use. In the study, we utilized the protocol for Type-it Microsatellite
\end{abstract}

\section{How to cite this book chapter:}

Ranković-Vasić, Z. and Nikolić, D. 2019. DNA Extraction and Application of SSR Markers in Genetic Identification of Grapevine Cultivars. In: Vucelić Radović, B., Lazić, D. and Nikšić, M. (eds.) Application of Molecular Methods and Raman Microscopy/Spectroscopy in Agricultural Sciences and Food Technology, Pp. 23-43. London: Ubiquity Press. DOI: https://doi.org/10.5334/bbj.c. License: CC-BY 4.0 
PCR Kit, optimized for fluorescent primers, and subsequent high-resolution fragment analysis by capillary sequencing instruments, following the Typeit Microsatellite PCR Handbook (Qiagen Inc.). The results of DNA analyses should be combined with ampelographic descriptors in identification of cultivars and planning the selection of grapevine varieties with desirable viticultural and enological values.

\section{Introduction}

Grapevine (Vitis vinifera L.) is one of the most valuable horticultural species. Currently, there are a large but imprecise number of grapevine cultivars in the world. In many regions have the synonyms (different names for the same cultivar) as well as homonyms (different cultivars identified under the same name). This number could likely be reduced once all cultivars are properly genotyped and compared. Identification of grapevine cultivars based on morphological differences between plants may be incorrect due to the influence of ecological factors. Therefore, methods for analysis at the cultivar genotype level have been developed. In the last twenty years, various techniques for the characterization of cultivars at the level of DNA (RFLP, RAPD, AFLP, SCAR and SSR markers) and isoenzymes have been established. The most appropriate for genotyping are those, using microsatellite markers (Jakše et al. 2013). In the past decade, the application of methods for molecular characterization has been significantly enhanced, particularly, DNA technology in ampelography, helping to identify varieties and their origin. Microsatellite markers (SSR markers) are widely used in grapevine genetic research for identification of cultivars, parentage analysis, and genetic characterization of germplasm. Microsatellites or simple sequence repeats (SSRs) have proved to be the most effective markers for grapevine genotyping (Sanchez-Escribano et al. 1999; Laucou et al. 2011). Thomas and Scott (1993) first used microsatellites for the identification of grapevine cultivars and demonstrated that microsatellite sequences are often represented in the grapevine genome and are very informative for the identification of Vitis vinifera cultivars. Hundreds of microsatellite markers for grapevines have been developed and most of them are publicly available (Bowers et al. 1996; Arroyo-Garcia \& Martinez-Zapater, 2004; Adam-Blondon et al. 2004; Merdinoglu et al. 2005; Cipriani et al. 2008). A set of six (VVS2, VVMD5, VVMD7, VVMD27, VrZag62, VrZAG79) or nine (previous six, combined with the following three: VVMD32, VVMD36, VVMD25) microsatellite markers has been used in grapevine genotyping studies, mostly for determining genetic variability among European grapevine cultivars, which are highly polymorphic (Sefc et al. 2001; This et al. 2004; Žulj et al. 2013). Aim of this research was extraction total DNA, primer selection and design, PCR protocols and analysis of DNA sequences with special emphasize on variability between collected samples of different grapevine cultivars. 


\section{Materials, Methods and Notes}

\subsection{Plant material}

The material used in this study, were the samples of grapevine leaves of different grapevine cultivars. The source of the material was either the developed leaves from vines in the vineyard from collection "Brogdale", UK (leaves should be the size of a few centimeters, Fig. 1a, b, c), and leaves obtained from cuttings in the laboratory (the method of "provocation"), from collection "Radmilovac", Serbia (Fig. 2a, b).

\section{Note:}

- You can not use partially developed or fully developed buds (Fig. 3).

- Buds have a high concentration of protein.

- Isolation of DNA will fail (will be very difficult) if extraction is carried out from the buds (if used Kit); would not provide adequate DNA concentration.

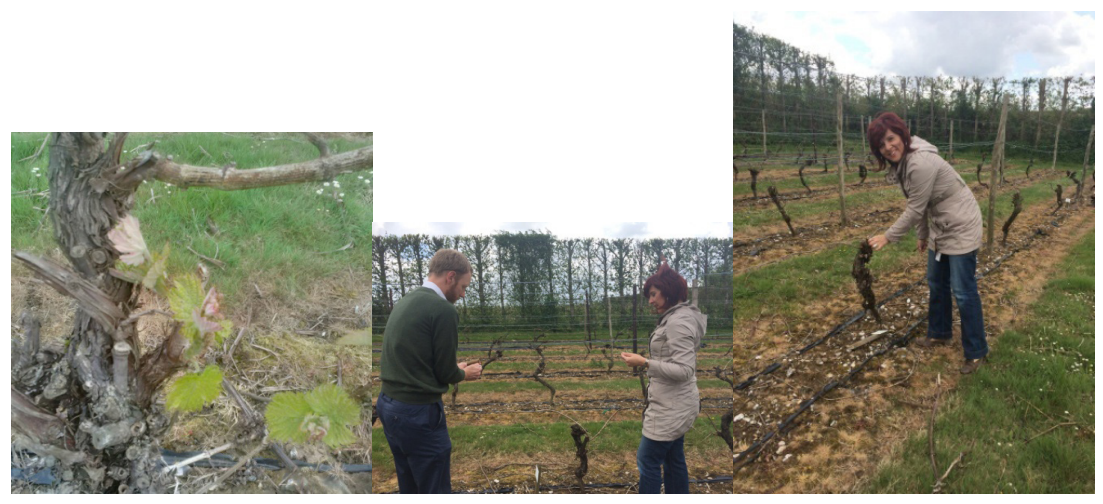

Figure 1: Collection of plant material from the vineyard.

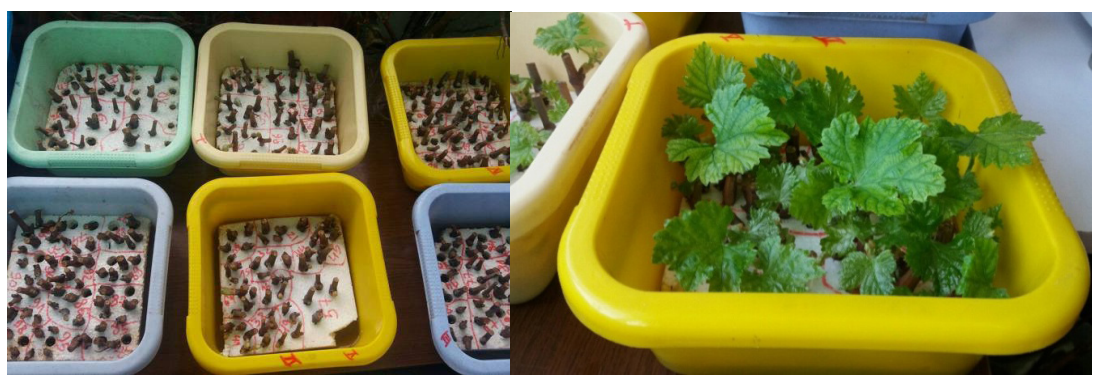

Figure 2: Plant material obtained from cuttings in the laboratory. 


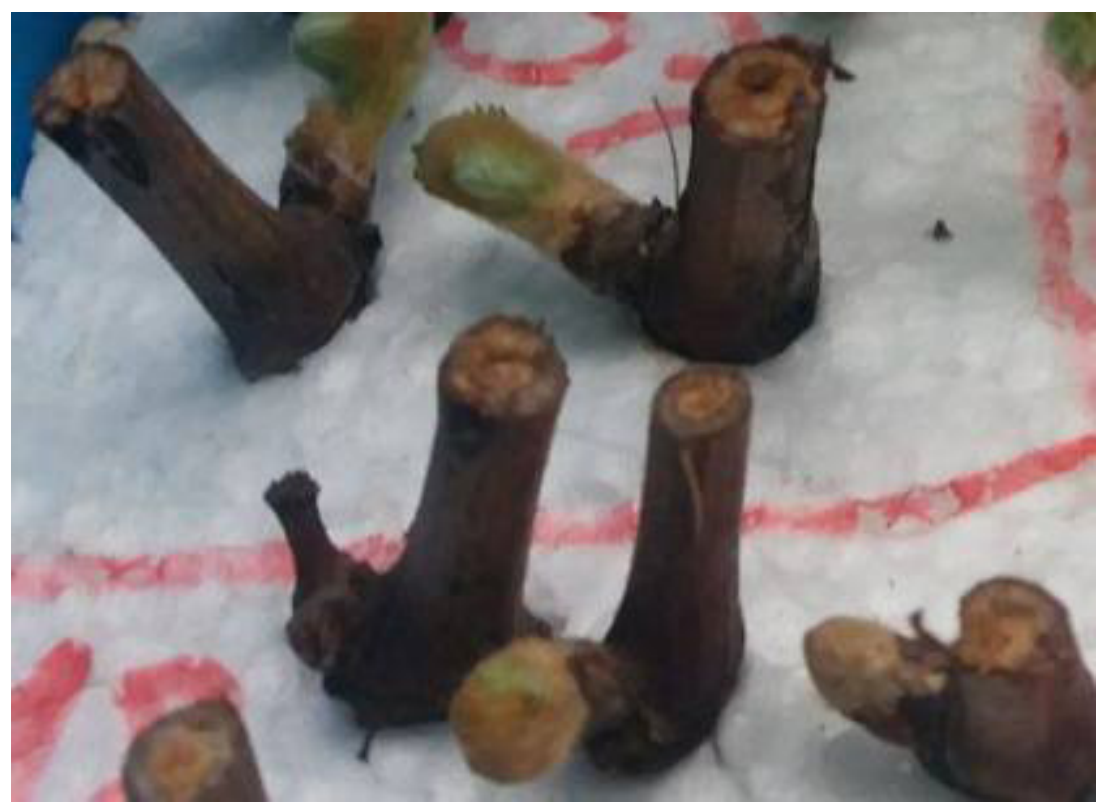

Figure 3: Buds.

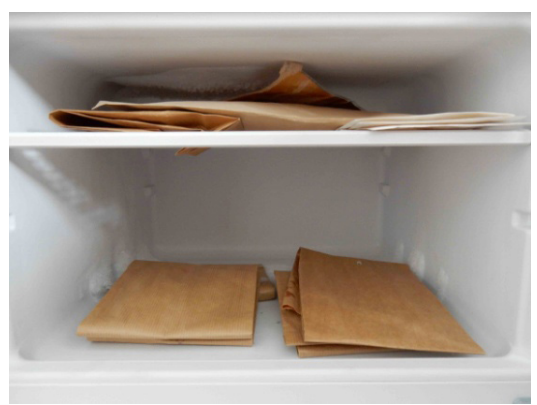

Figure 4: Leaves in the freezer.

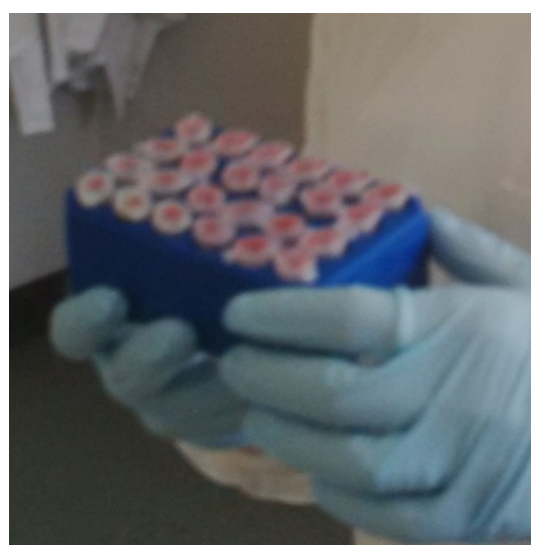

Figure 5: Tubes for sample keeping .

- The leaves can be kept in the freezer (in paper bags) until the beginning of DNA isolation (Fig. 4)

- The samples can be kept in the 1.5 or $2 \mathrm{ml}$ tubes $\left(-20^{\circ} \mathrm{C}\right)$ (Fig. 5).

- The samples can be lyophilized (weight about $20 \mathrm{mg}$ ), but the extracted DNK is not of desirable quality (Fig. 6). 


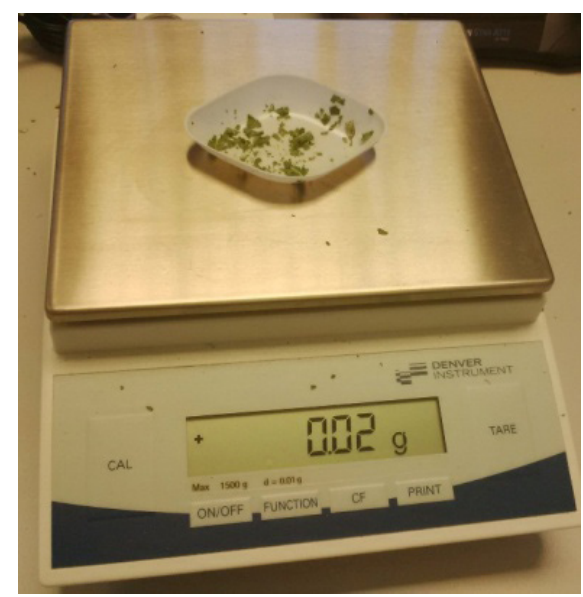

Figure 6: Measurement of the sample weight.

- Working with lyophilized samples is more difficult (weight measurement of samples is complicated).

- Each sample must have a code.

\subsection{DNA extraction}

Extraction and purification of total DNA from fresh or frozen plant material (grapevine leaves) was performed using a DNeasy ${ }^{\circledR}$ Plant Mini Kit following the standard protocol for isolation of DNA from plant leaf tissue outlined in the DNeasy Plant protocol handbook (Qiagen Inc.).

Notes before starting:

- Perform all centrifugation steps at room temperature $\left(15-20^{\circ} \mathrm{C}\right)$.

- If necessary, redissolve any precipitates in buffer AP1 and buffer AP3/E concentrates.

- Add ethanol to buffer AW and buffer AP3/E concentrates.

- Preheat a water bath or heating block to $65^{\circ} \mathrm{C}$.

\section{Extraction protocol:}

1. Plant leaves (about 150-170 mg fresh material) (Fig. 7) are grinded under liquid nitrogen (Fig. 8) to a fine powder using a mortar and pestle (Fig. 9) or Tissue Lyser (Fig. 10). The tissue powder and liquid nitrogen were transferred to $1.5 \mathrm{ml}$ tube and allowed the liquid nitrogen to evaporate (Fig. 11). 


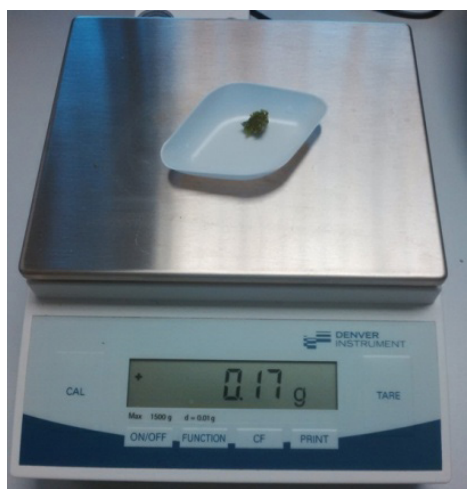

Figure 7: Measurement of the sample weight.
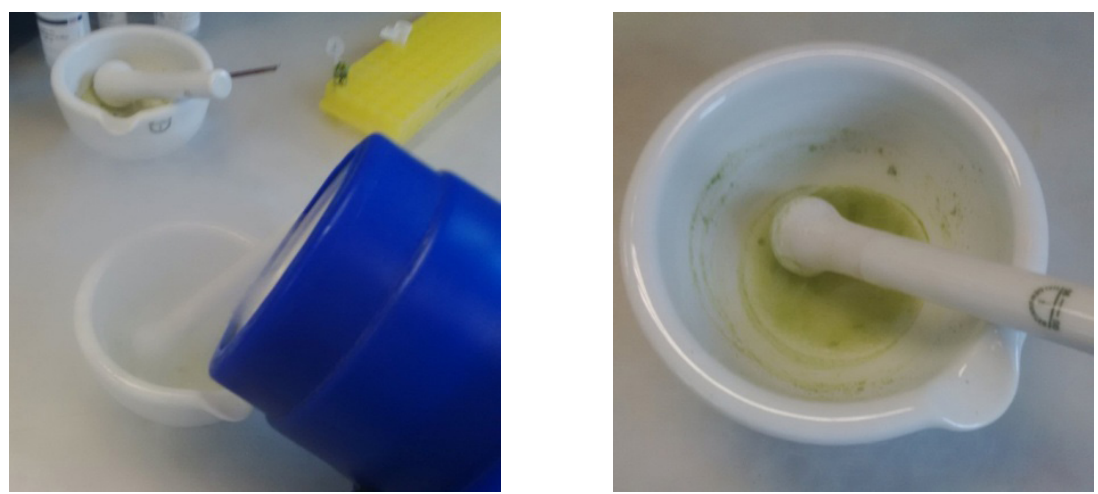

Figure 8 \& 9: Grinding under liquid nitrogen.

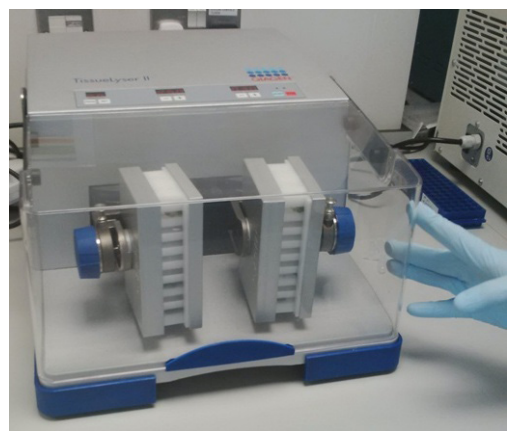

Figure 10: Grinder.

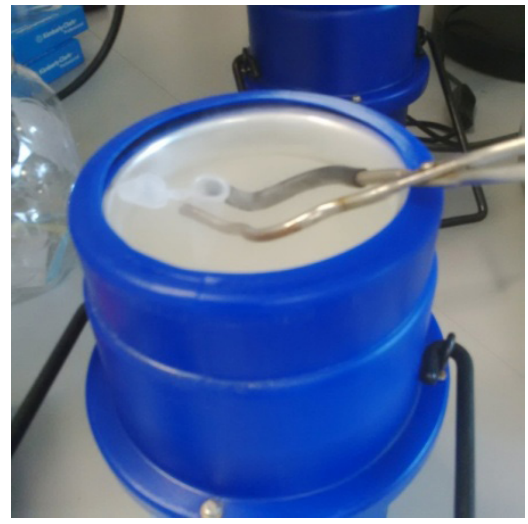

Figure 11: Tubes for samples. 
2. $400 \mu \mathrm{l}$ of Buffer AP1 and $4 \mu \mathrm{l}$ of RNase were added into the tube(s) with material and vortexed vigorously (Fig. 12).

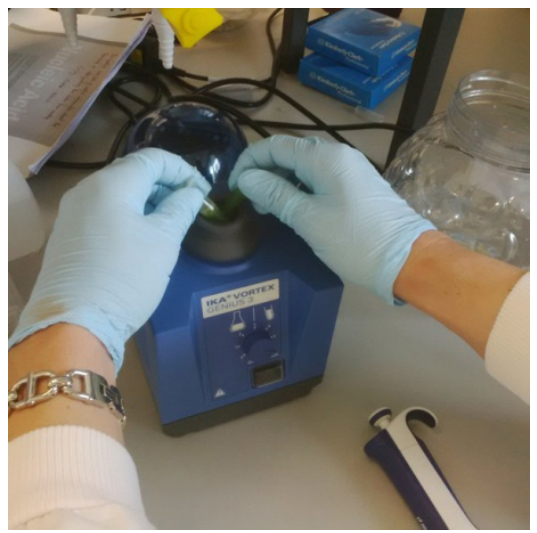

Figure 12: Vortexing.

3. The tubes were incubated at $65^{\circ} \mathrm{C}$ for $10 \mathrm{~min}$ on Termomixer that was set up to shake from 450 to $500 \mathrm{rpm}$ (Fig. 13). During this step cells were lysed.

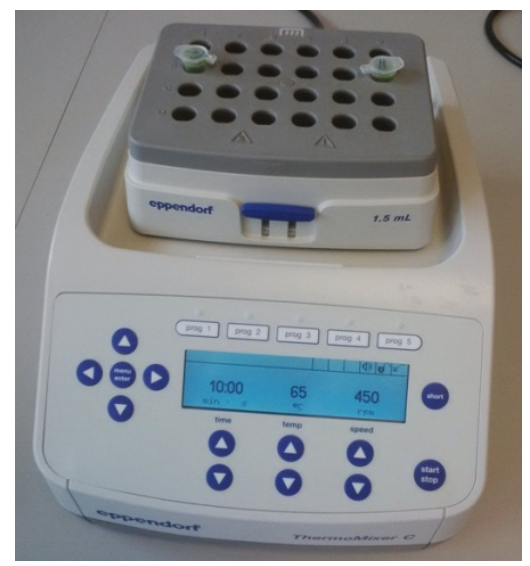

Figure 13: Termomixing.

4. $130 \mu \mathrm{l}$ of Buffer AP2 (P3) were added to the lysate, mixed, and tubes were incubated for $5 \mathrm{~min}$ on ice. During this step detergent, proteins and polysaccharides were precipitated. The tubes with lysate were centrifuged for $5 \mathrm{~min}$ at $14000 \mathrm{rpm}$ speed (or on max $14680 \mathrm{rpm}$ ) in order to remove the precipitates (Fig. 14). The samples in the centrifuge must be uniformly distributed (in equilibrium) (Fig. 15). 


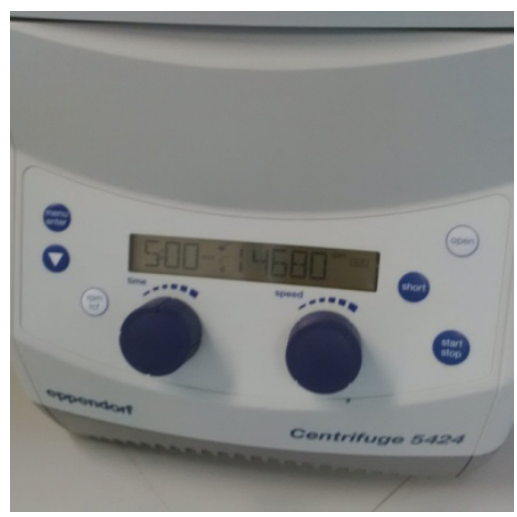

Figure 14: Centifugation.

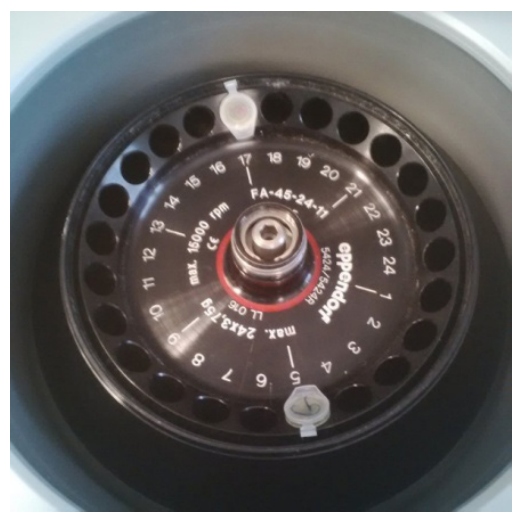

Figure 15: Position of the samples in centrifuge.

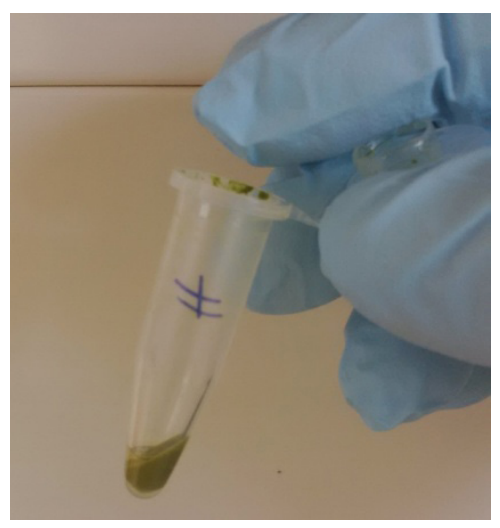

Figure 16: Lysate.

5. The obtained lysate (Fig. 16) was applied to the QIAshredder spin column placed in a $2 \mathrm{ml}$ collection tube (with pink cover) and centrifuged for $2 \mathrm{~min}$ at $14000 \mathrm{rpm}$ speed (or max speed on $14680 \mathrm{rpm}$ ).

6. The flow-through fraction $(400-450 \mu \mathrm{l})$ from step 5 was transferred to a new tube without disturbing the cell-debris pellet.

7. $600 \mu \mathrm{l}$ of Buffer AW1 were added to the cleared lysate and mixed by pipetting.

8. $650 \mu \mathrm{l}$ of the mixture from step 7 were transferred to the DNeasy mini spin column sitting in a $2 \mathrm{ml}$ collection tube and centrifuged for $1 \mathrm{~min}$ at $8000 \mathrm{rpm}$. After that flow-through were discarded.

9. The centrifugation at $8000 \mathrm{rpm}$ for $1 \mathrm{~min}$ was repeated.

10. DNeasy column were placed in a new $2 \mathrm{ml}$ collection tube and $500 \mu \mathrm{l}$ Buffer AW2 (AW) were added to the DNeasy column and centrifuged for $1 \mathrm{~min}$ at $8000 \mathrm{rpm}$. After that flow-through were discarded. 
11. $500 \mu \mathrm{l}$ Buffer AW2 (AW) were added to the DNeasy column and centrifuged for $2 \mathrm{~min}$ at $14000 \mathrm{rpm}$ (or max $14680 \mathrm{rpm}$ ) to dry the membrane. It is important to dry the membrane of the DNeasy column since residual ethanol may interfere with subsequent reactions. This spin ensures that no residual ethanol will be carried over during elution. After centrifugation flow-through were discarded.

12. The DNeasy column were transferred to a $1.5 \mathrm{ml}$ tubes and pipeted $60 \mu \mathrm{l}$ of preheated $\left(65^{\circ} \mathrm{C}\right)$ Buffer AE directly onto the DNeasy membrane. The column were incubated for $5 \mathrm{~min}$ (may be up to $15 \mathrm{~min}$ utes) at room temperature and then centrifuged for $1 \mathrm{~min}$ at 8000 rpm to elute DNA.

13. Step 12 was repeated.

14. The filter is removed. Tube with the DNA sample should be closed and placed on ice.

\section{Note:}

- Always mark the tubes used in the extraction.

- Take care of the cleanliness of the desk.

- The working surface has to be cleansed several times during the procedure

- Always wear clean gloves (change the gloves several times during the work).

- For each pipetting must be put new sequel to the pipette.

\subsection{Measuring the DNA concentration}

Spectrophotometry is used to determine the concentration of DNA in the sample. The concentration of extracted DNA was measured by NanoDrop spectrophotometer (Fig. 17) and storage on $-20^{\circ} \mathrm{C}$ until use.

\section{Procedure:}

1. Turn on the laptop.

2. On the screen click NanoDrop 2000.

3. Click on Nucleic Acid.

4. $1.5 \mu \mathrm{l}$ of blank Buffer AE were added on the needle spectrophotometer.

5. Spectrophotometers closed.

6. Click on the blank.

7. Wait for sensing.

8. Wipe the spectrophotometer needle with a paper towel.

9. $1.5 \mu \mathrm{l}$ DNA sample from ice were added on the spectrophotometer needle.

10. Click on measure. Typical DNA Spectrum is shown in the Fig. 18a and the one obtained during measuring of extracted DNA from our samples is shown in Fig. 18b. 

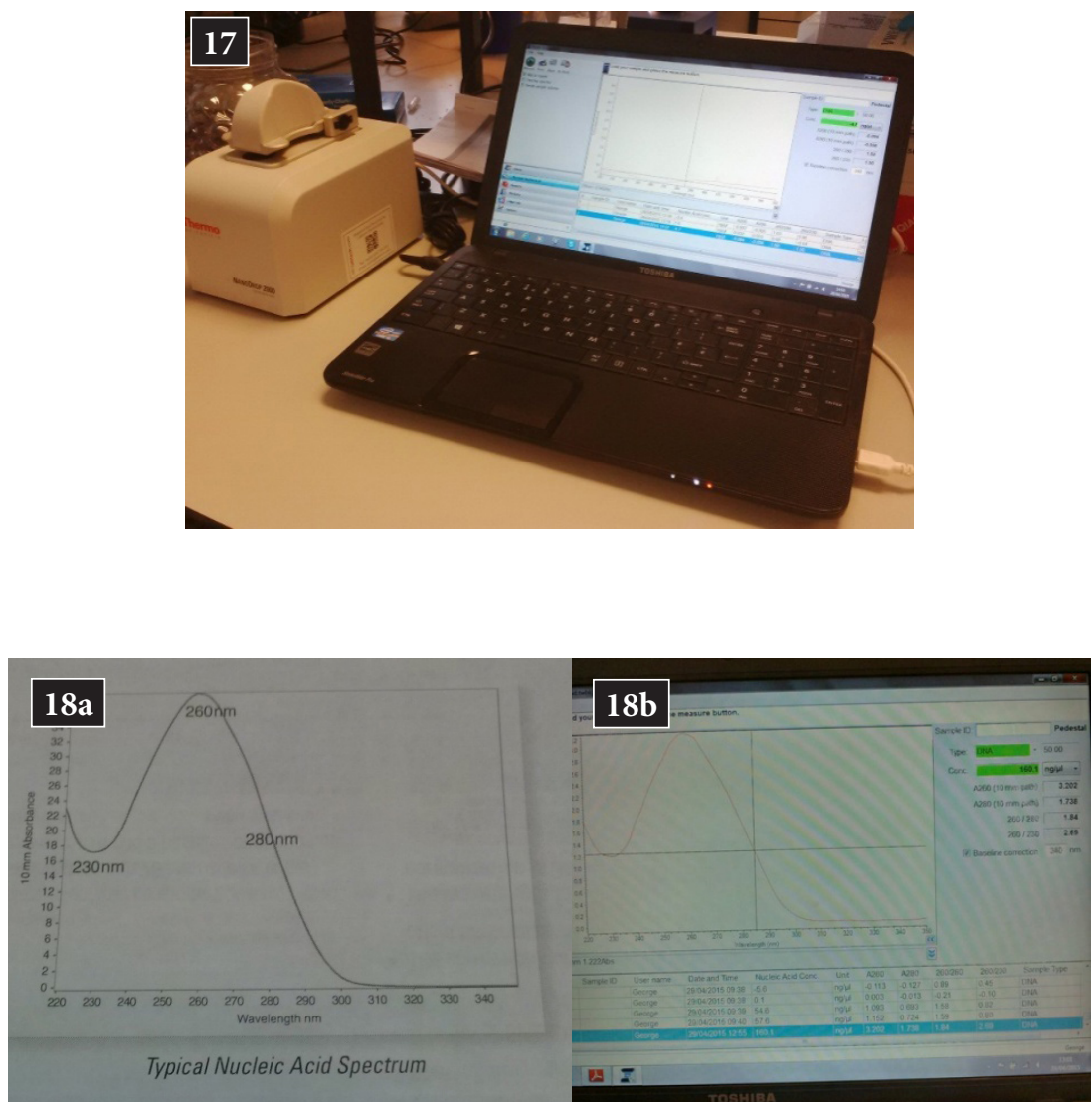

Figures 17, 18a and 18b: Measuring the DNA concentration.

\begin{tabular}{|c|c|c|c|c|c|}
\hline Code & Conc. DNA $(\mathbf{n g} / \boldsymbol{\mu l})$ & $\mathbf{A 2 6 0}$ & $\mathbf{A 2 8 0}$ & $\mathbf{2 6 0 / 2 8 0}$ & $\mathbf{2 6 0 / 2 3 0}$ \\
\hline 28 & 175.6 & 3.513 & 1.907 & 1.84 & 2.66 \\
\hline 31 & 128.3 & 2.566 & 1.439 & 1.78 & 2.05 \\
\hline 32 & 335.8 & 6.716 & 3.660 & 1.84 & 2.60 \\
\hline 34 & 89.3 & 1.786 & 0.975 & 1.83 & 2.76 \\
\hline
\end{tabular}

Table 1: Measured concentration of DNA in different grapevine cultivars.

\section{Note:}

- When configuring, spectrophotometer must be closed.

- When the blank is read, should not get any spectrum on the screen (without spectrum).

- Good concentration of DNA is shown in Table 1. 
- The ration of 260/280 and 260/230 must be higher of 1.7, for extracted DNA, to be considered as high-quality material, suitable for further analyses.

- In addition to estimate the quality of purified total DNA by calculating the ration $260 / 280$ and $260 / 230$, we also analyzed all samples by gel electrophoresis (see 2.6.1).

\subsection{PCR amplifications}

\subsubsection{Microsatellite analysis}

Analysis was performed using nine microsatellite loci: VVS2 (Thomas and Scott, 1993), VVMD5, VVMD7, VVMD25, VVMD27, VVMD28, VVMD32 (Bowers et al., 1996, 1999), VrZAG62 и VrZAG79 (Sefc et al., 1999). This set of highly polymorphic markers was used by the European Grape-Gen06 consortium (http://www1.montpellier.inra.fr/grapegen06/accueil.php) as the standard set for the screening of grapevine collections. Equivalent list primers for Vitis vinifera L. is shown in Table 2. All forward primers were labeled with 6-FAM, VIC, PET, or NED fluorescent dyes.

\section{Note:}

The DNA analyses should be combined with ampelographic descriptions, IPGRI, UPOV, OIV (1997) in planning the selection of grapevine varieties with desirable viticultural and enological value.

\section{Material needed for PCR amplification:}

1. Taq enzyme mix

2. Primers ( $\mathrm{R}$ and $\mathrm{F}$ )

3. Samples

4. Deionized water

Master mix (for 1 sample):

1. Taqenzymemix $(10 \times 1 \mu \mathrm{l})$

2. Primers $\mathrm{R}(0.7 \mu \mathrm{l})$

3. Primers F $(0.7 \mu \mathrm{l})$

4. Deionized water $(7.6 \mu \mathrm{l})$

\section{Note:}

- Total of master mix is $19 \mu \mathrm{l}$.

- All this is carefully shaken with pipette about 20 times.

- A volume of master mix components is multiplied by the number of samples (for bigger number of samples). 


\begin{tabular}{|c|c|c|c|c|c|c|c|c|c|c|c|c|c|c|c|c|c|c|}
\hline 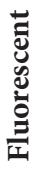 & $\sum_{\frac{1}{6}}$ & & $\sum_{\frac{1}{6}}$ & & $\frac{1}{1}$ & & $\frac{1}{\mathrm{z}}$ & & $\frac{7}{\mathrm{Z}}$ & & $\sum_{\frac{1}{6}}^{5}$ & & $\frac{5}{6}$ & & $\frac{5}{2}$ & & 9 & \\
\hline 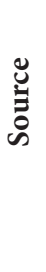 & 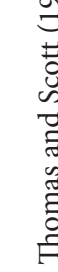 & & 20 & 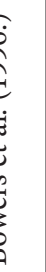 & a & & 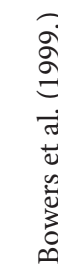 & & 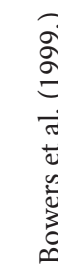 & & 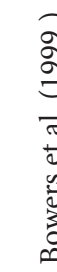 & & 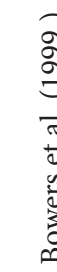 & & 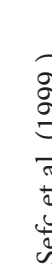 & & 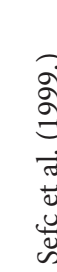 & \\
\hline 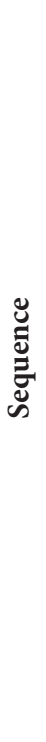 & 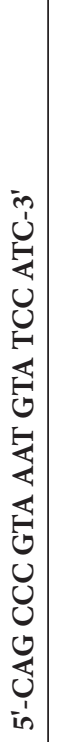 & 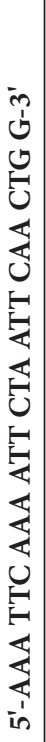 & 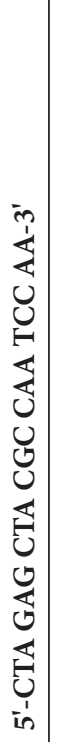 & 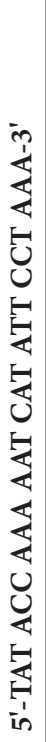 & 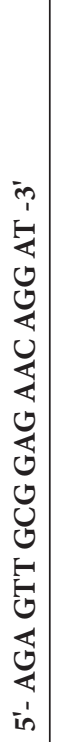 & 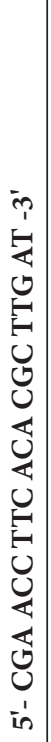 & 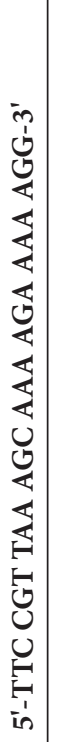 & 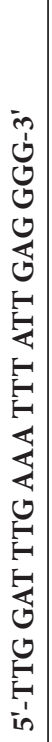 & 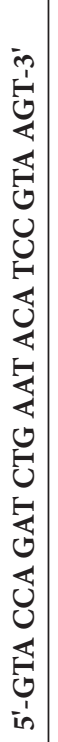 & 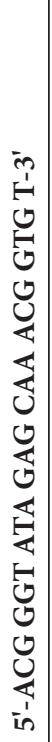 & 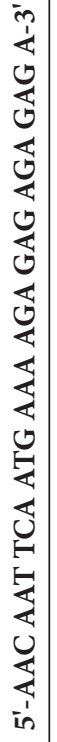 & 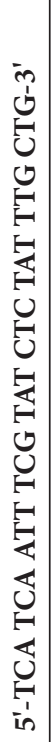 & 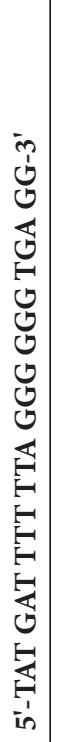 & 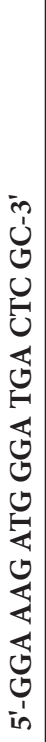 & 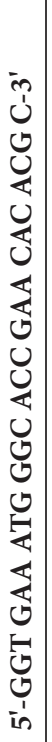 & 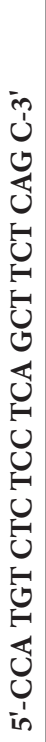 & 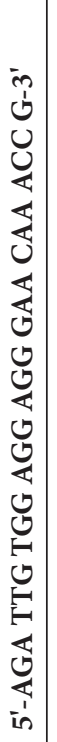 & 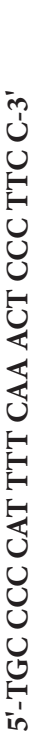 \\
\hline & 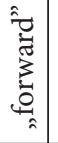 & 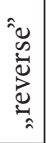 & 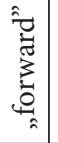 & 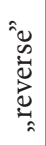 & 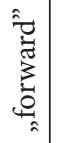 & 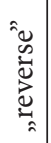 & $\begin{array}{l}\hat{0} \\
0 \\
3 \\
3 \\
0 \\
0 \\
0\end{array}$ & 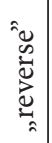 & $\begin{array}{l}\hat{\tilde{0}} \\
\overline{0} \\
3 \\
0 \\
0 \\
0 \\
0\end{array}$ & 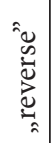 & 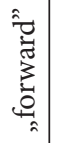 & 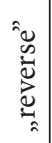 & 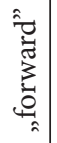 & 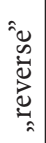 & 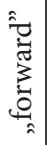 & 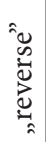 & 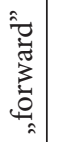 & 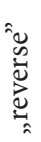 \\
\hline שֶ & \multicolumn{2}{|l|}{$\frac{1}{5}$} & \multicolumn{2}{|l|}{$\sum_{j}^{n}$} & \multicolumn{2}{|l|}{$\sum_{j}^{\hat{S}}$} & \multicolumn{2}{|l|}{ 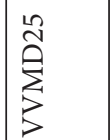 } & \multicolumn{2}{|l|}{$\underset{⿱ 丶}{\stackrel{1}{3}}$} & \multicolumn{2}{|l|}{ 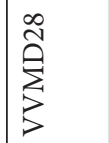 } & \multicolumn{2}{|l|}{ 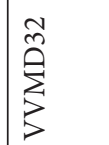 } & \multicolumn{2}{|l|}{ 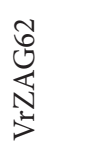 } & \multicolumn{2}{|l|}{ 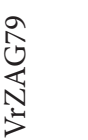 } \\
\hline
\end{tabular}




\section{Procedure:}

1. In the PCR tube add $1 \mu \mathrm{l}$ isolated DNA and $19 \mu \mathrm{l}$ master mix.

2. In the control PCR tube add $1 \mu \mathrm{l}$ deionized water and $19 \mu \mathrm{l}$ master mix.

3. Centrifuge for 1-2 sec.

4. Sett of PCR machine - Veriti ${ }^{\mathrm{TM}}$ Thermal Cycler (Applied Biosystems, Foster City, California, USA) (Fig. 19).

\section{Note:}

- PCR machine typically works about 1.30 hours.

- Depending on primers and overall experimental design, the different temperature and time settings could be used (Fig. 20). Different temperature is shown in Table 3.

- PCR reactions in a Veriti ${ }^{\mathrm{TM}}$ Thermal Cycler (Applied Biosystems, Foster City, California, USA) using the following conditions: $94^{\circ} \mathrm{C}$ for $2 \mathrm{~min}, 35$ cycles of $1 \mathrm{~min}$ at $94^{\circ} \mathrm{C}, 1 \mathrm{~min}$ at $50^{\circ} \mathrm{C}$, and $1 \mathrm{~min}$ at $72^{\circ} \mathrm{C}$, with a final extension of $30 \mathrm{~min}$ at $72^{\circ} \mathrm{C}$.

- PCR reactions in a GeneAmp PCR 9700 thermocycler (Applied Biosystems, Foster City, CA) using the following conditions: $94^{\circ} \mathrm{C}$ for $5 \mathrm{~min}, 30$ cycles of $1 \mathrm{~min}$ at $94^{\circ} \mathrm{C}, 1 \mathrm{~min}$ at $51^{\circ} \mathrm{C}$ or $49^{\circ} \mathrm{C}$ (for multiplex or singleplex PCR, respectively), and $1 \mathrm{~min}$ at $72^{\circ} \mathrm{C}$, with a final extension of $30 \mathrm{~min}$ at $72^{\circ} \mathrm{C}$.

- Can be used singleplex and multiplex reactions. Two multiplex PCR reactions were carried out for five (VVS2, VVMD7, VVMD27, VrZAG62, VrZAG79) and three (VVMD25, VVMD28, VVMD32) of the analyzed SSR a singleplex for VVMD5 (Vilanova et al. 2009).

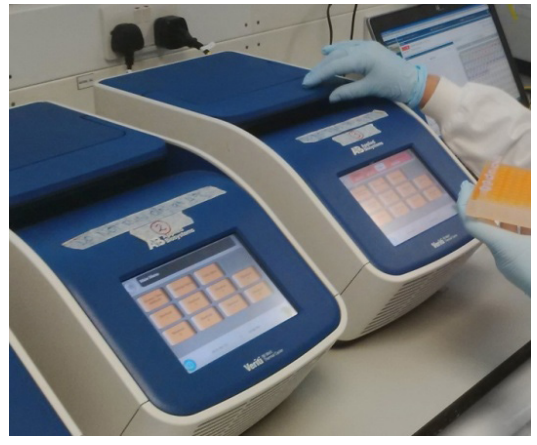

Figure 19: PCR mashine.

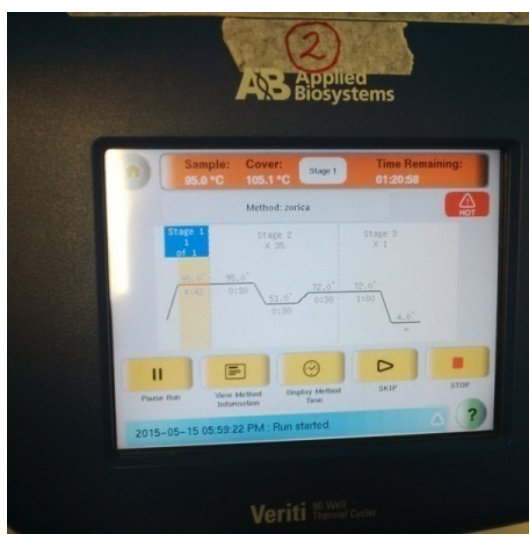

Figure 20: PCR mashine settings. 


\begin{tabular}{|c|c|c|c|c|c|}
\hline \multirow[b]{2}{*}{$\begin{array}{c}\text { PCR } \\
\text { amplification } \\
\text { steps }\end{array}$} & \multicolumn{5}{|c|}{ Primer } \\
\hline & $\begin{array}{c}\text { VVS2, } \\
\text { VVMD5, } \\
\text { VrZAG79, } \\
\text { VVMD7 }\end{array}$ & $\begin{array}{l}\text { VVMD27 } \\
\text { VVMD28 }\end{array}$ & VrZAG62 & \multicolumn{2}{|c|}{$\begin{array}{l}\text { VVMD25 } \\
\text { VVMD32 }\end{array}$} \\
\hline $\begin{array}{l}\text { Precycle/ } \\
\text { Initialization }\end{array}$ & $95^{\circ} \mathrm{C} 1 \mathrm{~min}$ & $94^{\circ} \mathrm{C} 2 \mathrm{~min}$ & $94^{\circ} \mathrm{C} 2 \mathrm{~min}$ & $94^{\circ} \mathrm{C} 2 \mathrm{~min}$ & \multirow{5}{*}{$\begin{array}{l}30 \mathrm{x} \\
\text { or } \\
35 \mathrm{x}\end{array}$} \\
\hline Denaturation & $95^{\circ} \mathrm{C} 30 \mathrm{sec}$ & $92^{\circ} \mathrm{C} 40 \mathrm{sec}$ & $92^{\circ} \mathrm{C} 40 \mathrm{sec}$ & $92^{\circ} \mathrm{C} 40 \mathrm{sec}$ & \\
\hline Annealing & $\begin{array}{l}51^{\circ} \mathrm{C} 30 \mathrm{sec} \\
\left(57-58^{\circ} \mathrm{C},\right. \\
30 \mathrm{sec}) \\
\left(48-56^{\circ} \mathrm{C},\right. \\
30 \mathrm{sec})\end{array}$ & $\begin{array}{l}55-56^{\circ} \mathrm{C} \\
30 \mathrm{sec} \\
49^{\circ} \mathrm{C} 30 \mathrm{sec}\end{array}$ & $\begin{array}{l}56-59^{\circ} \mathrm{C} \\
40 \mathrm{sec}\end{array}$ & $\begin{array}{l}44-45^{\circ} \mathrm{C} \\
30 \mathrm{sec} \\
48-49^{\circ} \mathrm{C} \\
30 \mathrm{sec}\end{array}$ & \\
\hline $\begin{array}{l}\text { Elongation/ } \\
\text { Extension }\end{array}$ & $72^{\circ} \mathrm{C} 30 \mathrm{sec}$ & $72^{\circ} \mathrm{C} 2 \mathrm{~min}$ & $72^{\circ} \mathrm{C} 2 \mathrm{~min}$ & $72^{\circ} \mathrm{C} 2 \mathrm{~min}$ & \\
\hline $\begin{array}{l}\text { Postcycle/Final } \\
\text { elongation }\end{array}$ & $72^{\circ} \mathrm{C} 1 \mathrm{~min}$ & $72^{\circ} \mathrm{C} 5 \mathrm{~min}$ & $72^{\circ} \mathrm{C} 5 \mathrm{~min}$ & $72^{\circ} \mathrm{C} 5 \mathrm{~min}$ & \\
\hline
\end{tabular}

Table 3: Suggestions of different temperature for different primers in PCR.

\subsection{Preparing for sequencing analysis (Protocol for Purification of PCR Products):}

Transfer PCR reaction mixture (whole quantity, about $35 \mu \mathrm{l}$ ) to a $1.5 \mathrm{ml}$ microfuge tube (blue cover) and add 3 volumes of Binding buffer 1 (105 $\mu$ l). Then, according to the protocol described in DNA Cleanup Handbook at http://www.nbsbio.co.uk/downloads/DNA_Cleanup_Handbook.pdf

1. Transfer the above mixture solution to the spin column and keep it at room temperature for 2 minutes. Centrifuge at $10000 \mathrm{rpm}$ for 2 minutes. Discharge the eluate from the tube.

2. Add $750 \mu \mathrm{l}$ of Wash solution to the column and spin at $10000 \mathrm{rpm}$ for 2 minutes.

3. Repeat the previous washing procedure using the same conditions. In order to remove any residual wash solution, extend spinning duration for 1 minute.

4. Place the column into a clean $1.5 \mathrm{ml}$ tube and add 30-50 $\mu$ (usually 30 $\mu \mathrm{l})$ of Elution buffer exactly into center of the column. Leave it at room temperature for 2 minutes (can also stand for 5 minutes). Centrifuge at $10000 \mathrm{rpm}$ for 2 minutes to elute the DNA.

\section{Note:}

- The incubation of the column, with the Elution buffer, at higher temperatures (up to $50^{\circ} \mathrm{C}$ ) may slightly increase the yield especially for large DNA. 
- The purified DNA can be stored at $4^{\circ} \mathrm{C}$ for immediate use or in a deep freezer at $-20^{\circ} \mathrm{C}$ for use in future.

- It is recommended to use the DNA Gel Extraction Kit if non-specific amplified DNA fragments are formed in a PCR experiment.

\subsection{Electrophoresis}

Electrophoresis is a method that is used to separate DNA fragments and determine their sizes by comparing them to the sizes of known fragment lengths. In our protocol, we applied this meted to test purified total DNA (2.2.) and the PCR products (2.4.)

\subsubsection{Gel Electrophoresis}

Procedure for making agarose gel:

1. Measure $0.25 \mathrm{~g}$ of the agarose and $25 \mathrm{ml} \times 1$ of TAE buffer $(100 \mathrm{ml}$ TAE $\times$ 10 add $1000 \mathrm{ml}$ distilled water).

Note: Agarose gels: Commonly are used concentrations of agarose gel from $0.7 \%$ to $2 \%$ depending on the size of bands needed to be separated. Measure $0.60 \mathrm{~g}$ of the agarose and $60 \mathrm{ml} \times 1$ of TAE buffer for biggest size electrophoresis box. Simply adjust the amount of starting agarose to $\% \mathrm{~g} / 100 \mathrm{~mL}$ TAE (i.e. $2 \mathrm{~g} / 100 \mathrm{~mL}$ will give you $2 \%$ ).

2. Dissolve agarose by heating in microwave oven (20-30 sec).

Note: Caution HOT! Be careful stirring, eruptive boiling can occur.

3. Let agarose solution cool down for $5 \mathrm{~min}$.

4. According to https://www.addgene.org/protocols/gel-electrophoresis/ add ethidium bromide (EtBr) to a final concentration of approximately $1.0 \mu \mathrm{g} / \mathrm{ml}$. Ethidium bromide binds to the DNA and allows visualization of the DNA when the gel is exposed to ultraviolet (UV) light.

Note:

- EXTREME CAUTION! It is known that ethidium bromide is a mutagen. It is necceassary to wear gloves, a laboratory coat and safety glasses when using this techique.

- Mildori Green Nucleic Acid Staning Solution is a safe alternative to traditional EtBr stain for detecting DNA in agarose gels.

5. Position the well comb in place and pour the agarose into a gel tray.

Note: Avoid formation of air bubbles which will disrupt the gel network by pouring agarose solution slowly. If bubbles are formed use a pipette tip to push them away towards the edges of the gel.

6. Cool newly poured gel for 10-15 minutes in a refrigarator or let it cool at room temperature for 20-30 minutes, until it completely solidifies. 
Preparation of samples for electrophoresis:

1. Carefully load your samples DNA $(4 \mu \mathrm{l})$ on the plate designated for mixing sample with sample buffer.

2. Add loading buffer to each of your samples DNA ( $2 \mu \mathrm{l}$ "stop blue").

Procedure of placing gel in electrophoresis box:

1. Remove protection tape.

2. Put the tray in electrophoresis box.

3. Remove the comb.

4. Fill gel box with $1 \times$ TAE until the gel is covered.

Loading samples and running an agarose gel:

1. Carefully load a molecular weight ladder (DNA 1000) into the first lane of the gel (add 3-4 $\mu \mathrm{l})$.

2. Carefully load your DNA samples $(4 \mu \mathrm{l}$ of DNA $+2 \mu$ l of loading buffer "stop blue") into the additional wells of the gel (Fig. 21).

3. Carefully load a molecular weight ladder (DNA 1000) into the last lane of the gel (add 3-4 $\mu \mathrm{l})$.

4. Apply power supply at $80-150 \mathrm{~V}$ to the gel until the dye reaches approximately $25-20 \%$ of the way from the end of the gel (Fig. 22).

\section{Note:}

- Negatively charged DNA molecules will move towards the positive electrode. Always place the gel in such a way that samples migrate towards positive electrode (red is positive electrode - connect it to the end of the gel; black is negative electrode - connect it to the start of the gel) (Fig. 23a, b).

- A typical run time is about 1-1.5 hours, depending on voltage.

5. Turn OFF power supply, disconnect the electrodes from the power source, and then carefully remove the tray with a gel from the gel box.

Note:

- TAE buffer can be replenished and used up to 10 times.

- Tape is obligatory placed at the gel box (write how many times used buffer) (Fig. 24).

- For a gel of small to mid-size, good separation of DNA fragments is achieved if gel is running at $50 \mathrm{~V}$ for about 45 minutes (Fig. 25). 

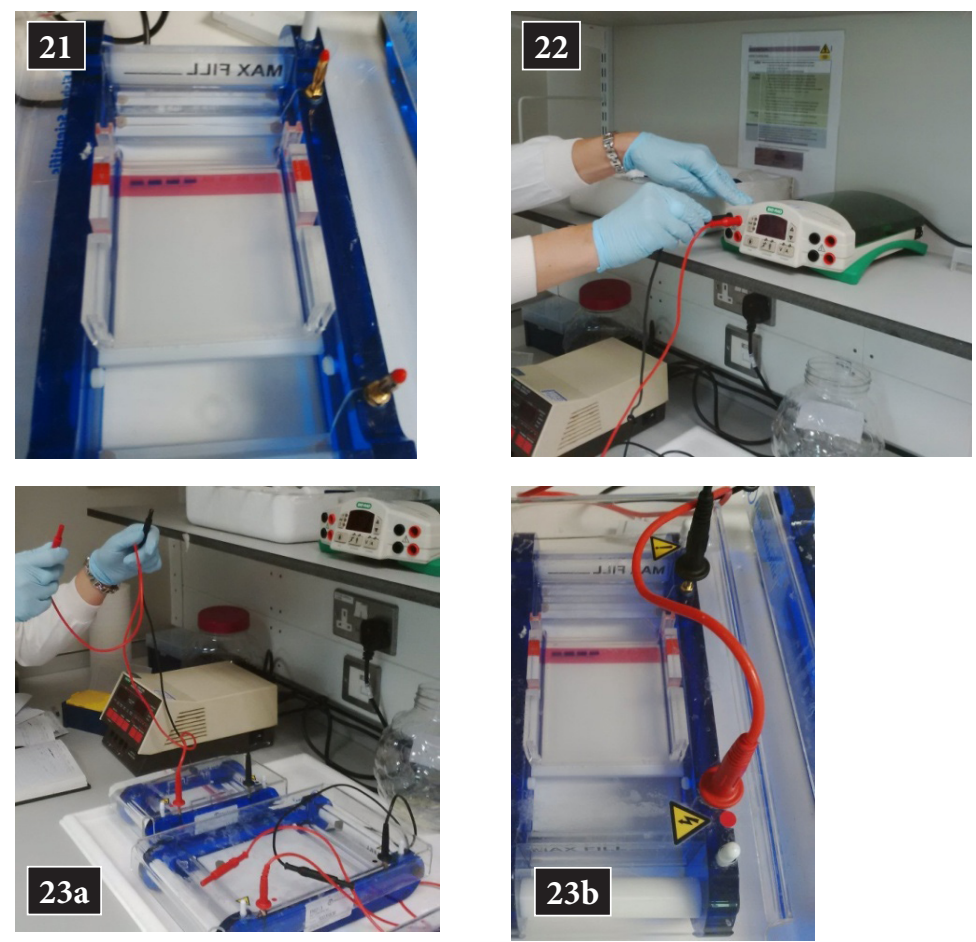

Figures 21., 22, 23a and 23b: Loading samples and running an agarose gel.

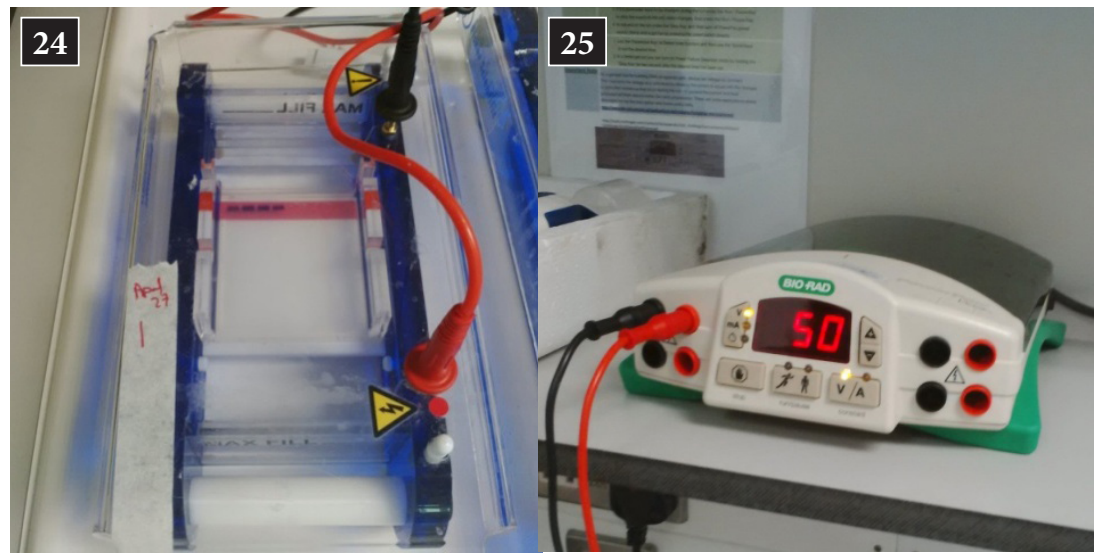

Figures 24. and 25: Electrophoresis apparatus. 


\subsection{Visualization of DNA fragments}

1. By using any device that has a source of UV light your DNA fragments will visualize and look like bands on the gel. According to https:// www.addgene.org/protocols/gel-electrophoresis/ pay attention to the following:

- UV light is very harmfool to your eyes and skin. Wearing protective glasses, gloves and laboratory coat is necessary.

- Using long-wavelength UV and the shortest possible exposition time will minimize damage to the DNA in the case that further analysis of DNA is planned.

2. Visualize DNA fragments by WP (GelDoc - It $\mathrm{It}^{\mathrm{TS} 2} / \mathrm{Imager}$ Benchop UV Transilluminator) (Fig. 26).

3. Gel in Transilluminator (Fig. 27).

4. Software: UVP TS2 (Fig. 28).

5. Printing by digital graphic printer UP-D897.

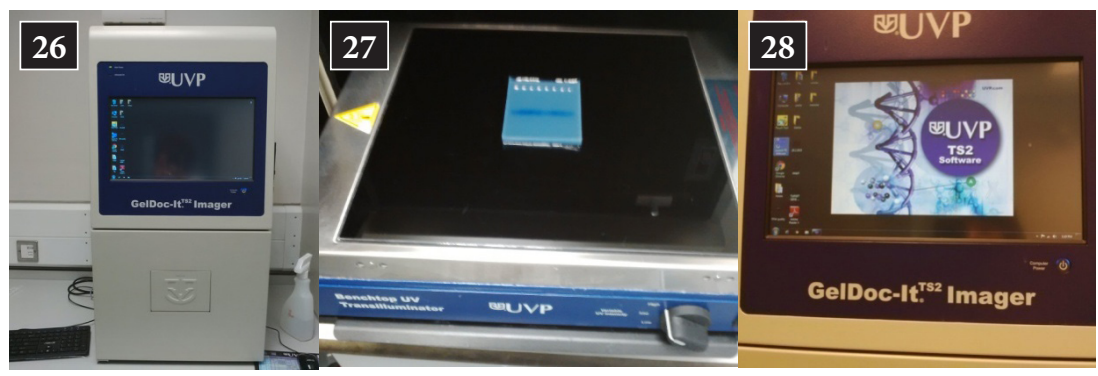

Figures 26., 27. and 28: Visualization of DNA fragments.

\subsection{Analyzing Gel:}

Use the DNA ladder, in the first lane, as a guide (the manufacturer's instruction will indicate the size of each band) to determine the length of the bands detected in the sample lanes and visualize purified total DNA (Fig. 29) and also visualize the PCR products (Fig. 30).

Note (according to https://www.addgene.org/protocols/gel-electrophoresis/):

- In order to get better resolution (crispness) of samples DNA bands lower voltage in a longer duration of a run can be used. Alternative is to choose a wider gel comb or to load lesser amount of DNA into the well.

- In order to get better separation of bands in the case of similarly sized fragments a higher percentage of agarose gel can be used to better separate smaller bands, and a lower percentage of agarose gel to separate larger bands. 


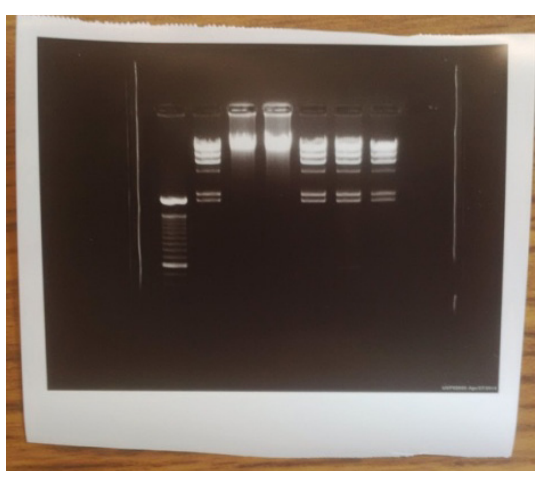

Figure 29: Visualisation of purified Figure 30: PCR products. total DNA.

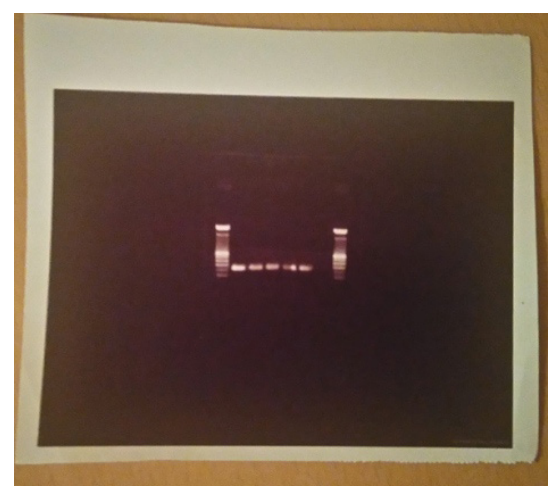

\section{Acknowledgements}

This work was realized as a part of project: FP7-REGPOT-2012-2013-1. No. 316004-AREA supported by the European Union. Investigations were carried thanks to the help and support dr George Gibbings, dr Matthew Ordidge, dr Tijana Blanusa, and dr Edward Paul Venison, from School of Agriculture, Policy and Development, University of Reading, Reading, UK

\section{References}

Agarose Gel Electrophoresis, Retrived from https://www.addgene.org/ protocols/gel-electrophoresis/

Adam-Blondon, A.F., Roux, C., Claux, D., Butterlin, G., Merdinoglu, D. \& This, P. (2004). Mapping 245 SSR markers on the Vitis vinifera genome: a tool for grape genetics. Theoretical and Applied Genetics, 109(5),1017-1027. DOI: https://doi.org/10.1007/s00122-004-1704-y

Arroyo-Garcia, R. \& Martinez-Zapater, J.M. (2004). Development and characterization of new microsatellite markers for grape. Vitis, 43(4),175-178.

Bowers, J.E., Vignani, R. \& Meredith, C.P. (1996). Isolation and characterization of new polymorphic simple sequence repeat loci in grape (Vitis vinifera L.). Genome, 39, 628-633, DOI. https://doi.org/10.1139/g96-080

Bowers, J.E., Dangl, G.S. \& Meredith, C.P. (1999). Development and characterization of additional microsatellite DNA markers for grape. American Journal of Enology and Viticulture, 50, 243-246.

Cipriani, G., Marrazzo, M.T., Di Gaspero, G., Pfeiffer, A., Morgante, M. \& Testolin, R. (2008). A set of microsatellite markers with long core repeat optimized for grape (Vitis spp.) genotyping. Bmc Plant Biology, 8(127), 1-13. DOI: https://doi.org/10.1186/1471-2229-8-127 
DNA Cleanup Handbook, Retrived from http://www.nbsbio.co.uk/downloads/ DNA_Cleanup_Handbook.pdf

Jakse, J., Štajner, N., Tomić, L. \& Javornik, B. (2013). Application of microsatellite markers in grapevine and olives. Agricultural and Biological Sciences " "The Mediterranean Genetic Code - Grapevine and Olive", book edited by Danijela Poljuha and Barbara Sladonja, Intech Open Science, DOI: https:// doi.org/10.5772/53411

Laucou, V., Lacombe, T., Dechesne, F., Siret, R., Bruno, J.P., Dessup, M., Dessup, T., Ortigosa, P., Parra, P., Roux, C., Santoni, S., Varès, D., Péros, J.P., Borsiquot, J.M. \& This, P. (2011). High throughput analysis of grape genetic diversity as a tool for germplasm collection management. Theoretical and Applied Genetics, 122(6),1233-1245. DOI: https://doi.org/10.1007/s00122010-1527-y

Merdinoglu, D., Butterlin, G., Bevilacqua, L., Chiquet, V., Adam-Blondon, A.F. \& Decroocq, S. (2005). Development and characterization of a large set of microsatellite markers in grapevine (Vitis vinifera L.) suitable for multiplex PCR. Molecular Breeding, 15(4), 349-366. DOI: https://doi.org/10.1007/ s11032-004-7651-0

IPGRI, UPOV, OIV. (1997). Descriptors for Grapevine (Vitis spp.). International Union for the Protection of New Varieties of Plants, Geneva, Switzerland/Office International de la Vigne et du Vin, Paris, France/International Plant Genetic Resources Institute, Rome, Italy.

Sanchez-Escribano, E.M., Martin, J.R., Carreno, J. \& Cenis, J.L. (1999). Use of sequence-tagged microsatellite site markers for characterizing table grape cultivars. Genome, 42(1),87-93. DOI. https://doi.org/10.1139/g98-116

Sefc, K.M., Regner, F., Tutetschek, E., Gloessl, J. \& Steinkellner, H. (1999). Identification of microsatellite sequences in Vitis riparia and their applicability for genotyping of different Vitis species. Genome, 42, 367-373.

Sefc, K.M., Lefort, F., Grando, M.S., Scott, K., Steinkellner, H. \& Thomas, M.R. (2001). Microsatellite markers for grapevine: A state of the art. In: Molecular Biology and Biotechnology of Grapevine. Roubelakis-Angelakis KA, editor. Amsterdam: Kluwer Publishers, 407-438. DOI: https://doi. org/10.1007/978-94-017-2308-4

This, P.,Jung, A., Boccacci, P., Borrego, J., Botta, R., Costantinim, L., Crespan, M., Dangl, G.S., Eisenheld, C., Ferreira-Monteiro, F., Grando, S.,Ibáñez, J.,Lacombe, T., Laucou, V., Magalhães, R., Meredith, C.P., Milani, N., Peterlunger, E., Regner, F., Zulini, L. \& Maul, E. (2004). Development of a standard set of microsatellite reference alleles for identification of grape cultivars. Theoretical and Applied Genetics, 109(7), 1448-1458. DOI: https://doi. org/10.1007/s00122-004-1760-3

Thomas, M.R. \& Scott, N. (1993). Microsatellite repeats in grapevine reveal DNA polymorphisms when analysed as sequence-tagged sites (STSs). Theoretical and Applied Genetics, 86, 985-990. DOI: https://doi.org/10.1007/ BF00211051 
Vilanova, M., Fuente, de la M., Fernández-González, M. \& Masa, A. (2009). Identification of New Synonymies in Minority Grapevine Cultivars from Galicia (Spain) Using Microsatellite Analysis. American Journal of Enology and Viticulture, 60, 236-240.

Žulj Mihaljević, M., Šimon, S., Pejić, I., Carka, F., Sevo, R., Kojić, A., Gaši, F., Tomić, L., Jovanović Cvetković, T., Maletić, E., Preiner, D., Božinović, Z., Savin, G., Cornea, V., Maraš, V., Tomić Mugoša, M., Botu, M., Popa, A. \& Beleski, K. (2013). Molecular characterization of old local grapevine varieties from South East European countries. Vitis, 52(2), 69-76. 
